\title{
A hepatitis C-vírus-fertőzés és kezelésének költségvonzata
}

\author{
Makara Mihály dr. ${ }^{1}$ - Hunyady Béla dr. ${ }^{2,3}$ \\ ${ }^{1}$ Egyesített Szent István és Szent László Kórház, Budapest \\ ${ }^{2}$ Somogy Megyei Kaposi Mór Oktató Kórház, Gasztroenterológia Osztály, Kaposvár \\ ${ }^{3}$ Pécsi Tudományegyetem, I. Belgyógyászati Klinika, Pécs
}

\begin{abstract}
A hepatitis C-vírus-fertőzés a Föld lakosságának 2-3\%-át érinti és a betegséghez társuló egyéni következmények mellett igen jelentős össztársadalmi gazdasági problémát jelent. A kiadások elsősorban a nagyszámú fel nem ismert vagy előrehaladott stádiumban felismert betegnél kialakuló májcirrhosis szövődményeihez, a hepaticus encephalopathia, az ascites, a varixvérzés és a hepatocellularis carcinoma ellátásához, valamint a májátültetéshez kapcsolódnak. Nem elhanyagolhatók ugyanakkor a munkában töltött minőségi életévek számának csökkenése miatti veszteségek, valamint a fertőzés kezelésének költségei sem. Utóbbiak az új, interferonmentes terápiák megjelenésével némiképp megemelkedtek a korábbi, proteázgátlóval együtt vagy a nélkül alkalmazott pegilált interferon plusz ribavirin terápiákhoz képest, ugyanakkor komoly megtakarítást jelenthet, hogy lényegesen kevesebb mellékhatással és ehhez kapcsolódó költséggel kell számolni. A témakörben megjelent közlemények szerint a fertőzöttek szűrőprogramokkal történő megtalálása és hatékony készítményekkel történő kezelése rövid távon jelentős többletforrást igényel, de - túl azon, hogy a legtöbbször iatrogén úton okozott betegség meggyógyítása morális társadalmi kötelesség - hosszú távon egyértelmúen megtakarítást eredményez. Orv. Hetil., 2015, 156(21), 862-868.
\end{abstract}

Kulcsszavak: antivirális kezelés, direkt ható antivirális szerek, hepatitis C-vírus, interferon, költséghatékonyság

\section{Financial burden of hepatitis $C$ infection and its treatment}

The worldwide prevalence of hepatitis $\mathrm{C}$ infection is $2-3 \%$. In addition to its individual consequences, it generates huge financial impact on national level. In particular, lack of recognition or late diagnosis of the disease is associated with high rate of liver cirrhosis related complications (hepatic encephalopathy, ascites, variceal bleeding, hepatocellular carcinoma) and/or demands liver transplantation. Loss of quality assisted life years and/or those spent in employment, reduced work productivity, as well as costs of antiviral therapy also contribute to the financial burden. The costs of new interferon-free therapies may exceed the prices of previous pegylated interferon based therapies with or without protease inhibitors; however, shorter treatment durations and extremely low rates of severe side-effects with much less related expenses can reduce total costs of these treatments. In addition to the moral obligations, published cost-effectiveness analyses conclude that early diagnosis and treatment of this primarily iatrogenic infection through organized screening programs and wide access to effective therapies may lead to long term financial benefit.

Keywords: antiviral treatment, cost-effectiveness, direct acting antiviral agents, hepatitis C virus, interferon

Makara, M., Hunyady, B. [Financial burden of hepatitis C infection and its treatment]. Orv. Hetil., 2015, 156(21), 862-868.

(Beérkezett: 2015. március 30.; elfogadva: 2015. április 14.)

\section{Rövidítések}

ABT3D = ombitasvir/paritaprevir/ritonavir+dasabuvir; ASV = asunaprevir; $\mathrm{CHC}=$ krónikus $\mathrm{C}$-vírus hepatitis; $\mathrm{DCV}=$ daclatasvir; F0-F4 = májfibrosis-stádiumok; Gl-G7 = hepatitis C-vírus genotípusok; HCC = hepatocellularis carcinoma; $\mathrm{HCV}=$ hepatitis C-vírus; ICER = (incremental cost-effectiveness ratio) növekményi költséghatékonysági arány; IFN = in- terferon; LDV = ledipasvir; peg-IFN = pegilált interferon; $\mathrm{PI}=$ (protease inhibitor) proteázgátló szer; QALY $=$ (quality assisted life year) minőségi életév; RBV = ribavirin; RVR = (rapid viral response) rapid vírusválasz; $\mathrm{SMV}=$ simeprevir; SOF = sofosbuvir; SVR = (sustained viral response) tartós vírusválasz 
A hepatitis C-vírus-fertőzés globális probléma, ami a legközvetlenebbül érintett fertőzött személyeken és környezetükön kívül össztársadalmi, világméretű probléma, morális, szociális aspektusai mellett jelentős a gazdasági vonzata. Nem meglepő, hogy a kérdéskörrel kapcsolatban több nemzetközi szervezet/intézmény is foglalkozott $[1,2,3]$.

A betegséggel kapcsolatos társadalmi teher részben morális: a legtöbb beteg egészségügyi beavatkozás során (fóként 1993 előtti transzfúzió, vérkészítmény adása), iatrogén úton fertőződött, és jelentős részüknél progresszív, az életkilátásokat, a munkaképességet és az életminőséget negatívan befolyásoló krónikus májbetegség, májzsugor, májelégtelenség, májrák (HCC) alakul ki. Másrészt mindezeknek a késői következményeknek a kezelése, csakúgy, mint a fertőzés kezelése, jelentős anyagi terhet ró a társadalomra $[4,5]$.

A közlemény a ma már szinte minden beteg meggyógyítására lehetőséget adó új, igen hatékony interferonmentes (IFN-mentes) kezelési lehetőségek megjelenése kapcsán ezeket a gazdasági szempontokat tekinti át.

\section{A HCV-fertőzés epidemiológiája, a fertőzéshez kapcsolódó betegségteher}

Mennini és munkatársai a HCV-hez kapcsolódó betegségterhet és egészségügyi ráfordítást elemezte Olaszországban 1950 és 2030 között. Ennek során a betegség szakirodalomban közölt természetes lefolyására vonatkozó adatok alapján vetítették elöre a progresszió, az egyes szövődmények és a klinikai kimenetelek (HCC, varixvérzés, transzplantáció, mortalitás stb.) várható kialakulását (transition probability), és az ehhez kapcsolódó egészségügyi kiadásokat. Egyidejúleg az akkor rendelkezésre álló pegilált interferon+ribavirin (peg-

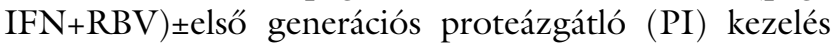
hatékonyságát és költségeit (kórházi felvételek, gyógyszerárak, terápia egyéb költségei) értékelték. Több mint 1,2 millióra becsülték a HCV-fertőzött egyének számát (prevalencia: 2,0-3,5\%), akik közül kevesebb mint 20\%ban volt ismert a betegség (211 000 fó), és utóbbiaknak csak körülbelül egytizedében történt kezelés (11 800 fö). A HCV-prevalencia csökkenése csak a szưrés és kezelésintenzitás növekedésétől várható, amellyel - kalkulációjuk szerint - 2030-ig csökkenhet a betegséggel kapcsolatos egészségügyi ráfordítás: a 2012-es évre kalkulált mintegy 527 millió euróról 2030-ra 346 millió euróra (34,3\% csökkenés). Amennyiben a 2012. évi kezelési intenzitás változatlan marad (11 800 beteg/év), de az új, 90\%-os hatékonyságú terápiákat alkalmazzák, a prevalencia 3\%-os csökkenését, a ráfordításigény 11,1 millió euró csökkenését prognosztizálják 2030-ig. Amennyiben pedig a terápiák hatékonysága mellett a kezelésintenzitás 10, illetve $50 \%$-kal emelkedik (12 790 beteg/év, illetve 16770 beteg/év), 18,4 millió, illetve 44 millió eurónyi megtakarítás várható - a direkt HCV elleni kezelések magas költségét is beszámítva. Egyidejüleg az évenkénti májeredetú halálozás a 2012. évi mintegy 16500 lakoshoz képest 13 000-12 700-12 500-11 500 lakosra csökkenhet [6].

A HCV szocioökonómiai terheit vizsgálta egy kérdőíves felmérés a munkaképesség, a nem munkához kapcsolódó aktivitás, az életminőség, az egészségügyi szolgáltatások igénybevétele és az ezzel kapcsolatos költségek vonatkozásában 286, nem kezelt HCV-fertőzött és megfelelően választott kontrollszemélyek válaszainak összehasonlításával. Valamennyi vizsgált paraméter vonatkozásában hátrányos helyzetben voltak a HCV-fertőzöttek. A becsült egészségügyi ráfordítás hatszor magasabb volt a HCV-fertőzötteknél (2956 euró versus 495 euró, p $<0,01$ ), míg a munkaképesség-csökkenéssel kapcsolatos, egy fertőzöttre jutó veszteség mintegy évi 2800 euró volt [7].

Az Amerikai Egyesült Államokban a HCV a májeredetû́ halálozás leggyakoribb oka, és az összes májátültetés 30\%-a emiatt történik. A Centers for Disease Control and Prevention (CDC) szervezet becslése szerint a betegséggel kapcsolatos egészségügyi ráfordítás mintegy 600 millió USD volt 1998-ban. A 2010 és 2019 közötti évtizedben a májeredetû halálozást 166 ezerre, a HCC miatti halálozást 27 ezerre becsülik, az ezek miatti egészségügyi kiadásokat pedig csaknem 11 millárd USD-re. Ezen belül a HCV miatti dekompenzált májcirrhosisos és/vagy HCC-vel megélt betegévet közel 721 ezerre, a 65 év alattiak körében az ezekkel kapcsolatos elveszített életéveket 1,83 millió évre, míg az elvesztett életévekkel kapcsolatos teljes veszteséget sorrenden 21,3, illetve 54,2 milliárd USD-re becsülik. Az előrevetítés a HCVfertőzés kezelés nélküli természetes lefolyásán, a különböző lehetséges kimenetelek irodalomban közölt valószínüségén alapult (1. táblázat) [8].

A közelmúltban Razavi és munkatársai több országra vonatkozóan elemezték a HCV-fertőzéshez kapcsolódó jelenlegi és várható betegségterheket. A HCV-gyakoriságot, a betegség természetes kimenetelét, a különböző szûrési és kezelési stratégiákat figyelembe véve arra a következtetésre jutottak, hogy a Magyarországhoz hasonló népességú Ausztriában, Belgiumban, illetve a Cseh Köztársaságban a jelenlegihez hasonló szúrési és kezelési aktivitás mellett 2013 és 2030 között várhatóan csökkenni fog a virémiás HCV-fertőzöttek száma (a Cseh Köztársaságban csak kismértékben), Belgiumban és a Cseh Köztársaságban azonban várhatóan növekedni fog az előrehaladott stádiumú (F3-F4) fertőzöttek száma, a kompenzált és dekompenzált cirrhosisosok száma, és mindhárom országban várhatóan növekedni fog a májeredetű halálozás és a hepatocellularis carcinoma előfordulása (2. táblázat). A 16 országra kiterjedő elemzés alapján az prognosztizálható, hogy Magyarországon akkor várható a fertőzöttek számának csökkenése (részben a sikeres kezelés, részben a halálozás eredményeként) az elkövetkező években, ha a fertőzött egyének felismerését szervezett szürőprogram segíti. Ebben az esetben 2025 után számíthatunk a HCV miatti májcirrhosis, dekom- 
1. táblázat $\mid$ A hepatitis C-vírus-fertőzés kezelés nélküli természetes lefolyása, a különböző lehetséges kimenetelek irodalomban közölt valószínúsége alapján [8]

\begin{tabular}{|c|c|c|}
\hline Kiinduló állapot & Kimenetel & $\begin{array}{l}\text { Évenkénti } \\
\text { valószínúség (\%) }\end{array}$ \\
\hline \multirow{2}{*}{$\begin{array}{l}\text { Enyhe krónikus } \\
\text { hepatitis }\end{array}$} & Remisszió & 0,2 \\
\hline & Moderált krónikus hepatitis & 4,1 \\
\hline \multirow{2}{*}{$\begin{array}{l}\text { Moderált krónikus } \\
\text { hepatitis }\end{array}$} & Cirrhosis & 7,3 \\
\hline & $\mathrm{HCC}$ & 0,1 \\
\hline \multirow[t]{4}{*}{ Cirrhosis } & Ascites & 2,5 \\
\hline & Varixvérzés & 1,1 \\
\hline & Encephalopathia & 0,4 \\
\hline & $\mathrm{HCC}$ & 0,5 \\
\hline \multirow[t]{2}{*}{ Ascites } & Refrakter ascites & 6,7 \\
\hline & Mortalitás & 11 \\
\hline Refrakter ascites & Mortalitás & 33 \\
\hline \multirow[t]{2}{*}{ Varixvérzés } & Mortalitás az első évben & 40 \\
\hline & Mortalitás első év után & 13 \\
\hline \multirow[t]{2}{*}{ Encephalopathia } & Mortalitás az első évben & 68 \\
\hline & Mortalitás első év után & 40 \\
\hline $\mathrm{HCC}$ & Mortalitás & 86 \\
\hline \multirow[t]{2}{*}{ Májátültetés } & Mortalitás az első évben & 21 \\
\hline & Mortalitás első év után & 5,7 \\
\hline
\end{tabular}

2. táblázat | Hepatitis C-vírus-fertőzöttség és ehhez kapcsolódó kimenetelek várható alakulása 2013 és 2030 között Ausztriában, Belgium ban, illetve a Cseh Köztársaságban [9]

\begin{tabular}{lllll}
\hline Paraméter & Év & Ausztria & Belgium & $\begin{array}{l}\text { Cseh } \\
\text { Köztársaság }\end{array}$ \\
\hline Népesség (millió) & 2013 & 8,4 & 10,2 & 10,6 \\
\hline $\begin{array}{l}\text { Virémiás prevalencia } \\
\text { (\%) }\end{array}$ & 2013 & 0,2 & 0,6 & 0,4 \\
\cline { 2 - 5 } $\begin{array}{l}\text { Virémiás fertőzött } \\
\text { (fó) }\end{array}$ & 2013 & 25400 & 67100 & 42500 \\
\hline $\begin{array}{l}\text { HCC-előfordulás } \\
\text { (fó) }\end{array}$ & 2013 & 13900 & 47700 & 42200 \\
\hline $\begin{array}{l}\text { Májeredetú } \\
\text { mortalitás (fó) }\end{array}$ & 2030 & 150 & 300 & 90 \\
\hline $\begin{array}{l}\text { Kompenzált } \\
\text { cirrhosis (fó) }\end{array}$ & 2013 & 100 & 290 & 80 \\
\hline $\begin{array}{l}\text { Dekompenzált } \\
\text { cirrhosis (fó) }\end{array}$ & 2013 & 2450 & 7060 & 1830 \\
\hline & 2030 & 180 & 1400 & 390 \\
\hline
\end{tabular}

penzált májcirrhosis, HCC és mortalitás, valamint az ezekkel kapcsolatos egészségügyi ráfordítás csökkenésére [9].

A betegséggel kapcsolatos kiadás az előrejelzések szerint 2024-ig az Amerikai Egyesült Államokban is növekedni fog (a 2000. évi 6,5 milliárd USD-ről 2024-re mintegy 9 milliárd USD), annak ellenére, hogy itt a pre- valencia már az 1990-es évek közepén tetőzött. Az egy HCV-fertőzött betegre fordított költséget mintegy 64500 USD-re becsülik [10]. Hasonlóan becsülték a fertőzöttséget és a következményeinek alakulását Kanadában is. A fertőzöttek száma 2013-ban már csökkenést mutatott a 2003. évi csúcshoz képest (mintegy 252 ezer fertőzött a 2003. évi 260 ezerről), de az előrehaladott stádiumban lévő májbetegek száma, az emiatt kialakuló dekompenzáció, szövődmények, HCC várható előfordulása, a mortalitás és az ezekhez kapcsolódó egészségügyi ráfordítás várhatóan 2032-ig növekedni fog. A HCV-kezelés költségeit nem számolva mintegy $60 \%$ ráfordításnövekedéssel kalkulálnak a 2013 és 2032 közötti időszakban, ez nagyrészt (> 80\%) várhatóan a májcirrhosissal és szövődményeivel lesz kapcsolatos. Az egy HCVfertőzött betegre fordított költséget az Amerikai Egyesült Államokhoz hasonlónak becsülik [11].

\section{A HCV elleni kezelések költséghatékonysága}

A gyógyszerárak önmagukban nem tükrözik a kezelések tényleges költségét. Az egyre hatékonyabb kezelési formákkal ugyanis az elköltött összegből egyre nagyobb számú beteg gyógyítható meg. A meg nem gyógyult betegre fordított költség ugyanakkor érdemben nem hasznosul. Így egy kezelési stratégia tényleges költséghatékonyságát nem az egy betegre jutó költség, hanem az egy meggyógyult betegre jutó költség jellemzi (költség/ SVR). Emellett az IFN-mentes kezelésekhez képest az IFN-alapú kezeléseknél jelentős költséghátrányt jelent a mellékhatások kezeléséhez szükséges további jelentős kiadás. Ezek a többletköltségek elsősorban a kórházi ellátást igénylő állapotokhoz (a betegek 2-6\%-a), a transzfúzióhoz (a betegek 3-6\%-a), és - azokban az országokban, ahol elérhetôk - a haemopoeticus stimulálófaktorok adásához (a betegek 20-50\%-a), a hosszabb és problémásabb kezelésekből adódó lényegesen nagyobb számú betegmegjelenéshez, a több PCR-vizsgálathoz és gyakoribb más laboratóriumi vizsgálatokhoz kapcsolódnak [12, 13, $14,15]$.

Az első generációs PI-készítmények (boceprevir, illetve telaprevir) bevezetésekor több tanulmány is foglalkozott azzal, vajon megéri-e és milyen módon éri meg leginkább ezek alkalmazása korábban nem kezelt betegek esetében. Egy átlagosan 50 éves olasz betegre vonatkozóan a peg-IFN+RBV lead in kezeléskor bekövetkező rapid vírusválasz (RVR) elmaradásakor alkalmazott boceprevirkezelést, telaprevir esetében a beteg interleukin-28B genotípusa szerint végzett kezelést találták költséghatékonynak. Markov-modell alapján a kezeléssel megnyerhető életévek száma 4-4,4 között volt, míg az évenkénti növekményi költséghatékonyság (ICER/ LYG: incremental cost-effectiveness ratio/life year gained) a hármas kezelések fenti módokon történő alkalmazása esetén 8304, illetve 11455 euróban becsülhető a peg-IFN+RBV kettős kezeléshez képest. Ez annyit je- 
lent, hogy korábban nem kezelt HCV-Gl-fertőzötteknél boceprevir alkalmazása RVR-t nem mutató betegeknél, míg telaprevir alkalmazása nem CC interleukin-28B genotípus esetén költséghatékony. Természetesen a költséghatékonyság konkrét gyógyszerárak, valamint az RVR, illetve a nem CC-genotípus-gyakoriságok függvénye [16].

A simeprevir megjelenését követően a költséghatékonysági elemzések azt mutatták, hogy ezzel a telapreviralapú hármas kezeléshez képest 0,235 év nyereség érhető el 263037 jen megtakarítással, a peg-IFN+RBV kezeléshez képest 0,873 év nyereséggel 776900 jen megtakarítással HCV-Gl-fertőzött betegeknél. Az elemzésben nem foglalkoztak a még újabb kezelési lehetőségekkel $[17,18]$.

Hasonló elemzések láttak napvilágot az új DAA-terápiák vonatkozásában is $[19,20,21,22,23,24]$. Liu és munkatársai fogvatartottaknál vizsgálták a nem kezelés, a peg-IFN+RBV kettős kezelés és ezekhez viszonyítva a boceprevir, illetve sofosbuvir (SOF) hármas kezelés várható kimenetelét, költséghatékonyságát. Számításuk szerint az egyes stratégiák mellett sorrendben 13,1213,57-14,43-15,18 minőségi életév (QALY) várható, a SOF-kezeléstől várható a dekompezált májcirrhosis (16\%) és a hepatocellularis carcinoma (HCC: 9\%) előfordulásának legnagyobb arányú csökkenése, és ez a kezelés bizonyult legköltséghatékonyabbnak (28 800 USD per QALY) [25]. A DAA hármas kombinációk közül az AbbVie hármas kombináció, illetve Harvoni-kezelés a megfelelő HCV Gl/4, illetve G2/3 fertőzött betegeknél az ismert listaárak alapján megtakarítást eredményezett a sofosbuvir+simeprevir, illetve sofosbuvir+ribavirin kombinációkhoz képest [26].

Az Amerikai Egyesült Államokban elérhető sofosbuvir, simeprevir, daclatasvir és ledipasvir sorrendben heti 7000-5500-5500-875 USD listaárát figyelembe véve HCV-Gl kezelésében a sofosbuvir-ledipasvir kombináció 12825 USD/QALY többletköltséget eredményezett a hagyományos hármas kombinációkhoz képest. HCV-G2 esetén a sofosbuvir-ribavirin, illetve sofosbuvir-daclatasvir 110000 USD/QUALY, illetve 691 000 USD/QALY többletköltséggel járt a pegilált interferon plusz ribavirin kezeléshez képest, míg HCV-G3 esetén a sofosbuvir-ledipasvir-ribavirin 73000 USD/QALY-ba, a sofosbuvir-daclatasvir pedig 396000 USD/QALY-ba került. Amennyiben a sofosbuvir-ledipasvir ára a 6375 USD-t nem haladná meg, ez a kombináció nemcsak a leghatékonyabb és legbiztonságosabb kezelési forma lehetne HCV-Gl-ben, hanem a legköltséghatékonyabb is (az AbbVie kombinációkkal nem kalkulálva) [27].

Hasonló eredményre jutottak Chbatwal és munkatársai. Eszerint a sofosbuvir-ledipasvir kezelés 0,56 QALY-t eredményez a hagyományos hármas kombinációkhoz képest, 55400 USD ICER/QALY költséggel. A költség 9700 USD ICER/QUALY és 284300 USD ICER/ QUALY között változhat, a betegek kezelési előzményei, a HCV-genotípus és a cirrhosis jelenléte szerint.
Az Amerikai Egyesült Államokban elfogadott 100000 USD/QALY költséghatárt figyelembe véve a betegek több mint $80 \%$-ánál minősül költséghatékonynak ez a kezelés - függetlenül a kezelési előzményektől. Ugyanakkor a sofosbuvir-ledipasvir kezelés a jelenlegi kezelési intenzitás mellett öt év alatt az eddigi ráfordításnál 16 milliárd USD-vel több, összesen 65 milliárd USD költséggel járna [28]. Előnyösnek találták e sofosbuvir/ledipasvir kezelést más közleményekben is, beleértve a HCV-Gl-fertőzött betegeket [29].

\section{A költséghatékony kezelés gyakorlata Magyarországon}

A HCV gyógyulásával (SVR) közel 5 év átlagos élettartam-növekedés, illetve több mint 4 év minőségi életév (QALY) nyerhető a számítások alapján [30]. A különböző kezelési formák esetében az ismert európai átlagárak mellett a peg-IFN+RBV kezelés (a stopszabályokat betartva) a legköltséghatékonyabb naïve betegek esetében, míg a proteázgátlók vonatkozásában a boceprevirrel végzett, korai vírusválasz (RVR) alapján irányított kezelés a legköltséghatékonyabb [16]. Az interferonmentes kezelések részben a magas gyógyulási arány, részben a mellékhatások elenyésző volta miatt bizonyulnak költséghatékonynak magas áruk ellenére még a betegség enyhébb fokozatának esetében is [31].

Hazánkban külön figyelembe kell venni, hogy a hepatitis C kezelésére fordítható összeg korlátozott, nevezetesen ez a magyar költségvetés részeként, a parlament által meghatározott éves keret. Ebből az összegből kell gazdálkodni úgy, hogy egyrészt a lehető legtöbb beteget meggyógyítsuk, másrészt, jusson pénz a legsúlyosabb, legelőrehaladottabb betegségben szenvedőknek mielőbbi kezelésére is, az esetükben kellően hatékony és biztonságos, általában IFN-mentes kombinációkkal. A hazai szakmai irányelv tehát költséghatékonysági szempontokat és költségvetési kihatásokat is figyelembe vesz.

A Hepatitis Regiszter (HepReg: www.hepreg.hu) adatai alapján az utóbbi években 500-600 új beteg kezelését kezdtük meg évente pegilált interferonnal és ribavirinnel (peg-IFN+RBV). Ugyanakkor egyre növekvő számú betegnél ellenjavallt az IFN-alapú kezelés, leginkább az előrehaladott májbetegség szövődményei miatt. A korábban nem kezelt betegek esetén az első választás gazdasági okból valószínúleg a peg-IFN+RBV marad: egy beteg meggyógyítása 25-30\% stopszabály és mellékhatás miatti leállással és 20-25\% relapsusarány figyelembevételével listaáron számolva 8-9 millió forint. Child A cirrhosis mellett az AbbVie3D (európai ismert kúraköltség 13 millió forint/12 hét), míg Child $B$ esetén a sofosbuvir és ledipasvir kombináció (európai ismert kúraköltség 16 millió forint/12 hét) alkalmazása jöhet szóba [32]. Mivel SVR esetén a megnyert minőségi életév 4 feletti, ezért 1 minőségi életévnyereség még a legdrágább kezelés mellett is 4 millió forint alatt, jóval a nemzetközileg elfogadott határ (20 000-120 000 USD/QALY) alá kerül [33]. Jelenleg 
nincsenek pontos adataink arra vonatkozóan, hogy a frissen felfedezett betegek hány százaléka rendelkezik interferon-ellenjavallattal, illetve hány százalékuk Child B stádiumú. A FibroScan-adatok elemzéséből azonban látszik, hogy a frissen diagnosztizált betegekben $23 \%$ a cirrhosis aránya. A beadott kérvényekben a korábban nem kezelt betegek 10\%-a volt Child B stádiumban.

Peg-IFN+RBV adása során a magyar protokollban rögzített stopszabályok betartása kötelező, amelyek szigorúbbak az alkalmazási előírásokban leírtaknál (1 ábra). Ha a kezelés 4 . hetére a vírusszám nem csökken $1 \log _{10}$-nél nagyobb mértékben, akkor a kezelést le kell állítani. Ilyen betegeknél a PI-vel kiegészített IFNalapú kezeléssel is szerények a kezelési eredmények $(<50 \%)$, és csak az interferonmentes kezeléseknek van értelme. A törzskönyvezés-vizsgálatokból az is nyilvánvaló, hogy egyrészt a „nullreszponderekben” a PI-t tartalmazó hármas kombinációk eredményessége alacsony, másrészt a sikertelen kezelések mellett rezisztencia kialakulása várható [17]. Amennyiben a peg-IFN+RBV kezelés 12. hetét követően a HCV-RNS kimutatható („target detected”), akkor vagy a kezelést kell leállítani, vagy - amennyiben a HCV-RNS titere csökkenésének mértéke nagyobb volt $2 \log _{10}$-nél és a prioritási index alapján várható, hogy a beteg a kezelésre az engedélyt megkapja - azonnal új kérvényt kell beadni PI-kezelésre. Költséghatékonysági szempontból azonban a PI-k esetén figyelembe kell venni a kezelés alatti rosszabb életminőséget, az alacsonyabb gyógyulási arányt az interferonra csak közepesen reagálók (parciális reszponderek) esetén, valamint azt, hogy az utóbbi betegcsoportban a rezisztencia kialakulására kell számítani, és sikertelen PI-vel végzett kezelés után csak a sofosbuvir+ledipasvir kombináció alkalmazásával vannak kellő tapasztalatok. Az ártárgyalások során kialkudott gyógyszerárak függvényében lehetséges, hogy minden kettős kezelésre nem vagy részlegesen reagáló betegnél az IFN-mentes terápia a legköltséghatékonyabb - szakmai szempontból és a betegérdekeket figyelembe véve pedig mindenképpen ennek lehetővé tétele a cél.

A korábbi peg-IFN+RBV kezelés után visszaeső (relabáló) betegek számára javasolható a proteázgátlót tartalmazó hármas kezelés. Itt 90\% körüli hatékonyság érhető el $[14,15,17]$. Természetesen, amennyiben az IFNmentes kezelések kellően megközelítik az interferonalapú hármas kezelések összköltségét, akkor ezeknél a betegeknél is az IFN-mentes kezelések részesítendők előnyben, kedvezőbb mellékhatásprofiljuk, a járulékos költségek csökkenése és egyúttal a kezelés alatti kedvezőbb életminőség miatt.

2015. márciusig már több mint 1100 IFN-mentes kezelésre rögzítettek kérvényt a kollégák. (Nem közölt adat a Hepatitis Regiszterből, www.hepreg.hu.) Az emelkedés dinamikájából arra következtethetünk, hogy

\section{Korábban nem kezelt betegek peginterferon+ribavirin kezelése (G1-G6)}

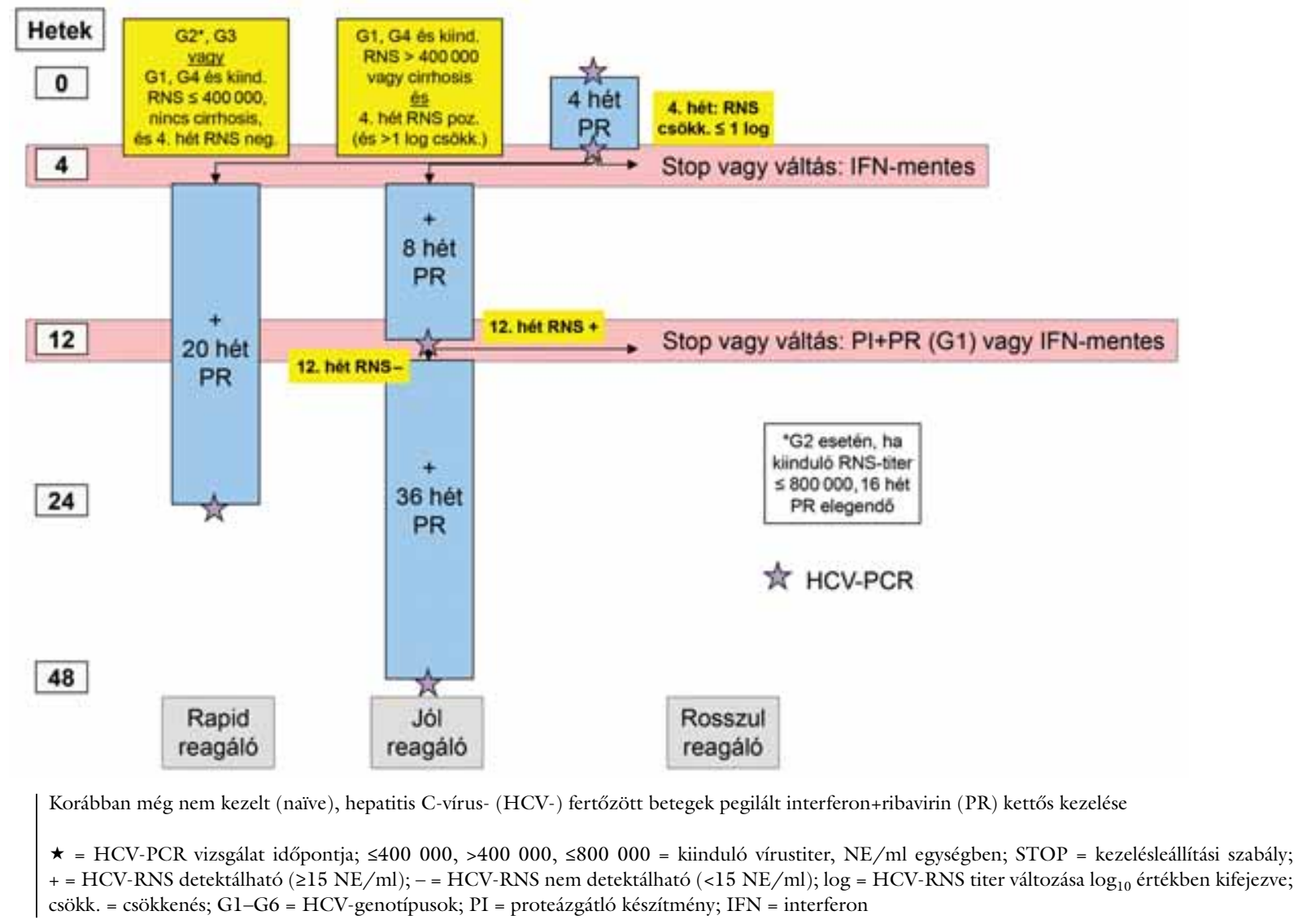


ebben az évben összesen 1500 beteg kérvénye kerül beadásra. Az eddig tapasztalt arányszámok alapján közülük 320 beteg korábban kezelésben részesült, 730 beteg csak kettős kezelésben részesült, amelyre intoleranciát mutatott vagy nullreszponder volt, míg 450 beteg korábban hármas, proteázgátló alapú kezelést kapott. A kérvényekben szinte kizárólag l-es genotípusú vírussal fertőzöttek szerepelnek. Az egyes csoportokban a májbetegség stádiumának megoszlása szerinti bontás a 3. táblázatban található.

Child-Pugh B stádiumban csak Harvoni adható, míg a többi betegszegmens számára HCV-Gl esetén az AbbVie 3D kombináció is szóba jön. A daclatasvir és asunaprevir kombináció használata csak lb genotípus esetén és csak akkor javasolható, ha az Országos Gyógyszerészeti Intézet az off-label kezelést a kezelőorvosokat jogi és etikai szempontból megnyugtató módon engedélyezi, és a kombináció ára lényegesen kedvezőbb a másik kettőnél, továbbá az NS5A L31 és Y93 kezelés előtti polimorfizmus kizárható. Mivel az OEP várhatóan sikeralapú finanszírozásra fogja kötelezni a gyógyszerforgamazókat (SVR-garanciát kell adniuk), ezért költséghatékonysági szempontból csak a kúraköltség árát kell figyelembe venni. Mellékhatásaik minimálisak, addicionális költségek nem merülnek fel.

\section{Következtetések}

A HCV-fertőzés igen hatékony és biztonságos új IFNmentes terápiáival szinte valamennyi fertőzöttnél tartós vírusmentesség érhetô el. Egy ebben érdekelt és ehhez forrásokkal rendelkező országban ez potenciálisan lehetővé teheti a vírus virtuálisan teljes eradikálását.

A kezeléssel kapcsolatos ráfordításigény két fó pillére valamennyi országban - így hazánkban is - a fertőzöttek felfedezését lehetôvé tévő hatékony szưrőprogram és a diagnosztizált betegek eredményes kezelését lehetôvé

\begin{tabular}{l|l} 
3. táblázat & $\begin{array}{l}\text { Az interferonmentes kezelésre váró betegek csoportonkénti } \\
\text { megoszlása a Hepatitis Regiszterben rögzített kezelési kérelmek } \\
\text { alapján }\end{array}$
\end{tabular}

\begin{tabular}{llllll}
\hline Kategória & $\begin{array}{l}\text { Össze- } \\
\text { sen }\end{array}$ & $\begin{array}{l}\text { F4b } \\
\text { CP-B /C }\end{array}$ & $\begin{array}{l}\text { F4 } \\
\text { CP-A }\end{array}$ & F3 & F0-2 \\
\hline $\begin{array}{l}\text { Korábban nem } \\
\text { kezelt, interferon- } \\
\text { ellenjavallt }\end{array}$ & 320 & 32 & 154 & 58 & 77 \\
$\begin{array}{l}\text { Korábban csak } \\
\text { pegilált } \\
\text { interferonnal } \\
\text { kezelt, interferon- } \\
\text { intolerancia }\end{array}$ & 730 & 73 & 292 & 183 & 183 \\
$\begin{array}{l}\text { Korábban } \\
\text { proteázgátlóval } \\
\text { is kezelt, } \\
\text { nem gyógyult }\end{array}$ & 450 & 45 & 216 & 108 & 81 \\
\hline
\end{tabular}

F0-F4 = fibrosis Metavir-stádium; CP-A, CP-B $/ \mathrm{C}=$ Child-Pugh A és B/C stádium tévő terápia költsége. A szürőprogram költsége a populáció nagyságából, valamint a szürés megszervezésével és lebonyolításával kapcsolatos költségekből jól kalkulálható: egy személy szúrését $3000 \mathrm{Ft}$ bekerülési költséggel kalkulálva a teljes hazai populációra vonatkozóan 30 milliárd Ft lehet. Jól becsülhető a teljes maximális terápiás költség is: a feltételezhető 20-30 ezer, még kezelést igénylő fertőzött személy kezelése 5 millió Ft/beteg kezelési költséggel kalkulálva 100-150 milliárd Ft-ra tehető. Hat éven át évenként 20-30 milliárd Ft ráfordítással tehát elvileg lényegében a teljes lakosság vírusmentessé válhatna - így gyakorlatilag újabb fertőzés kialakulásával (az esetleges bevándorlóktól eltekintve) alig kellene számolni. Ettől kezdődően nemcsak a fertőzés megelőzésére és kezelésére fordított költségek csökkenhetnének drámaian, hanem 2025-2030-tól az előrehaladott májbetegek kezelésére fordítandó kiadások is $20-30 \%$-kal csökkenhetnének.

Gazdasági kérdéssé egyszerüsödött tehát a vírus teljes eradikálása Magyarországon: társadalmi vita látszik indokoltnak az előbbiekben vázolt költségvonzatú nemzeti program támogatottságának megítélésére. Ennek lebonyolításáig és eldöntéséig is fontos azonban a jelenleg rendelkezésre álló források leghatékonyabb felhasználása, a lehető legnagyobb számú beteg meggyógyítása, és a legsúlyosabb állapotú betegek haladéktalan, hatékony és biztonságos IFN-mentes terápiával történő meggyógyítása.

Anyagi támogatás: A közlemény megírása anyagi támogatásban nem részesült.

Szerzôi munkamegosztás: A dolgozat elkészítésében a két szerző egyenlő arányban vett részt. A cikk végleges változatát mindkét szerző elolvasta.

Érdekeltségek: M. M.: Előadói/tanácsadói díjban és/ vagy kutatási támogatásban részesült az alábbi gyógyszer elóállítóktól/forgalmazóktól: AbbVie Kft., Boehringer Ingelheim, Bristol-Myers Squibb Kft., Fresenius-Kabi, Gilead Sciences, Janssen-Cilag Kft., MSD Kft., Merck Kft., Roche Magyarország Kft. H. B.: Előadói/tanácsadói díjban és/vagy kutatási támogatásban részesült az alábbi gyógyszer elóállítóktól/forgalmazóktól: AbbVie Kft., Boehringer Ingelheim, Bristol-Myers Squibb Kft., Fresenius-Kabi, Gilead Sciences, Janssen-Cilag Kft., MSD Kft., Merck Kft., Roche Magyarország Kft.

\section{Irodalom}

[1] European Parliament: Written declaration, under Rule 123 of Parliament's Rules of Procedure, on hepatitis B and C. 18/02/2014. http://www.europarl.europa.eu/sides/getDoc. do? type $=$ WDECL\&reference $=$ P7-DCL-2013-0023\&language $=$ EN\&format $=$ PDF

[2] World Health Organisation: WHO viral hepatitis resolution. 23/01/2010. apps.who.int/gb/ebwha/pdf_files/EB126/ B126_Rl6-en.pdf 
[3] Ulmer, T., Hughes, S.: Implementation guide on viral hepatitis policies for the European Union Member States. An expert group chaired by Dr. Thomas Ulmer MEP and Staphen Hughes MEP. 6/11/2013. www.spg.pt/wp-content/uploads/2014/ $03 /$ Implementation-Guide-on-Viral-Hepatitis-Policies-for-theEuropean-Union-Members-States.pdf

[4] Boesecke, C., Wasmuth, J. C.: Hepatitis C. In: Mauss, S., Berg, T. Rockstroh, J., et al. (eds.): Hepatology - A Clinical Textbook. Fifth edition. Flying Publisher, 2014. www.hepatologytextbook. com

[5] Lozano, R., Naghavi, M., Foreman, K., et al.: Global and regional mortality from 235 causes of death for 20 age groups in 1990 and 2010: a systematic analysis for the Global Burden of Disease Study 2010. Lancet, 2012, 380(9859), 2095-2128.

[6] Mennini, F. S., Marcellusi, A., Andreoni, M., et al.: Health policy model: long-term predictive results associated with the management of hepatitis $\mathrm{C}$ virus-induced diseases in Italy. Clinicoecon. Outcomes Res., 2014, 6, 303-310.

[7] Vietri, J., Prajapati, G., El Khoury, A. C.: The burden of hepatitis $\mathrm{C}$ in Europe from the patients' perspective: a survey in 5 countries. BMC Gastroenterol., 2013, 13, 16.

[8] Wong, J. B., McQuillan, G. M., McHutchison, J. G., et al.: Estimating future hepatitis $\mathrm{C}$ morbidity, mortality, and costs in the United States. Am. J. Public Health, 2000, 90(10), 1562-1569.

[9] Razavi, H., Waked, I., Sarrazin, C., et al: The present and future disease burden of hepatitis $\mathrm{C}$ virus ( $\mathrm{HCV}$ ) infection with today's treatment paradigm. J. Viral Hepat., 2014, 21(Suppl. 1), 34-59.

[10] Razavi, H., Elkhoury, A. C., Elbasha, E., et al.: Chronic hepatitis $\mathrm{C}$ virus (HCV) disease burden and cost in the United States. Hepatology, 2013, 57(6), 2164-2170.

[11] Myers, R. P., Krajden, M., Bilodeau, M., et al.: Burden of disease and cost of chronic hepatitis $\mathrm{C}$ infection in Canada. Can. J. Gastroenterol. Hepatol., 2014, 28(5), 243-250.

[12] European Medicines Agency: Pegasys. Instructions for use [Pegasys. Alkalmazási elöírás.] 23/06/2014. http://www.ema. europa.eu/docs/hu_HU/document_library/EPAR___Product_Information/human/000395/WC500039195.pdf [Hungarian]

[13] European Medicines Agency: PegIntron. Instructions for use. [PegIntron. Alkalmazási elöírás.] 11/06/2014. http://www. ema.europa.eu/docs/hu_HU/document_library/EPAR_Product_Information/human/000280/WC500039388.pdf [Hungarian]

[14] European Medicines Agency: Incivo. Instructions for use. [Incivo. Alkalmazási elóírás.] 22/09/2014. http://www.ema.europa. eu/docs/hu_HU/document_library/EPAR_-_Product_Information/human/002313/WC500115529.pdf [Hungarian]

[15] European Medicines Agency: Victrelis. Instructions for use. [Victrelis. Alkalmazási elóírás.] 27/08/2014. http://www.ema.europa.eu/docs/hu_HU/document_library/EPAR_-_Product_ Information/human/002332/WC500109786.pdf [Hungarian]

[16] Cammà, C., Petta, S., Enea, M., et al.: Cost-effectiveness of boceprevir or telaprevir for untreated patients with genotype 1 chronic hepatitis C. Hepatology, 2012, 56(3), 850-860.

[17] European Medicines Agency: Olysio. Instructions for use. [Olysio. Alkalmazási előírás.] 04/06/2014. http://www.ema.europa. $\mathrm{eu} /$ docs/hu_HU/document_library/EPAR___Product_Information/human/002777/WC500167867.pdf [Hungarian]

[18] Kuwabara, H., Westerhout, K., Treur, M., et al.: Cost-effectiveness analysis of simeprevir in combination with peginterferon and ribavirin for treatment-naïve chronic hepatitis $\mathrm{C}$ genotype 1 patients in Japan. J. Med. Econ., 2015 March 31. doi:10.3111/ 13696998.2015.1029492 [Epub ahead of print]

[19] European Medicines Agency: Sovaldi. Instructions for use. [Sovaldi. Alkalmazási elóírás.] 26/08/2014. http://www.ema.europa.
eu/docs/en_GB/document_library/EPAR_-_Product_Information/human/002798/WC500160597.pdf [Hungarian]

[20] European Medicines Agency: Daklinza. Instructions for use. [Daklinza. Alkalmazási elő́rás.] 15/09/2014. http://www. ema.europa.eu/docs/hu_HU/document_library/EPAR_Product_Information/human/003768/WC500172848.pdf [Hungarian]

[21] European Medicines Agency: Harvoni. Instructions for use. [Harvoni. Alkalmazási elóírás.] 04/12/2014. http://www.ema.europa.eu/docs/hu_HU/document_library/EPAR_-_Product_ Information/human/003850/WC500177995.pdf [Hungarian]

[22] Bristol-Myers Squibb: Japan approves first all-oral, interferon- and ribavirin-free hepatitis C treatment, Daklinza ${ }^{\circledR}$ (daclatasvir) and Sunvepra $^{\circledast}$ (asunaprevir) dual regimen. Press release. 07/07/2014. news.bms.com/press-release/japan-approvesfirst-all-oral-interferon-and-ribavirin-free-hepatitis-c-treatmentdakl

[23] European Medicines Agency: Exviera. Instructions for use. [Exviera. Alkalmazási elő́rás.] 12/02/2015. http://www.ema.europa.eu/docs/hu_HU/document_library/EPAR___Product_ Information/human/003837/WC500182233.pdf [Hungarian]

[24] European Medicines Agency: Viekirax. Instructions for use. [Viekirax. Alkalmazási elő́rás.] 09/03/2015. http://www.ema. europa.eu/docs/hu_HU/document_library/EPAR_-_Product_Information/human/003839/WC500183997.pdf [Hungarian]

[25] Liu, S., Watcha, D., Holodniy, M., et al.: Sofosbuvir-based treatment regimens for chronic, genotype 1 hepatitis $\mathrm{C}$ virus infection in U.S. incarcerated populations: a cost-effectiveness analysis. Ann. Intern. Med., 2014, 161(8), 546-553.

[26] Rein, D. B., Wittenborn, J. S., Smith, B. D., et al.: The cost-effectiveness, health benefits, and financial costs of new antiviral treatments for hepatitis C virus. Clin. Infect. Dis., 2015 March 16. pii: civ220. [Epub ahead of print]

[27] Najafzadeh, M., Andersson, K., Shrank, W. H., et al.: Cost-effectiveness of novel regimens for the treatment of hepatitis $\mathrm{C}$ virus. Ann. Intern. Med., 2015, 162(6), 407-419.

[28] Chhatwal, J., Kanwal, F., Roberts, M. S., et al.: Cost-effectiveness and budget impact of hepatitis $\mathrm{C}$ virus treatment with sofosbuvir and ledipasvir in the United States. Ann. Intern. Med., 2015, 162(6), 397-406.

[29] Younossi, Z. M., Park, H., Saab, S., et al.: Cost-effectiveness of all-oral ledipasvir/sofosbuvir regimens in patients with chronic hepatitis $\mathrm{C}$ virus genotype $\mathrm{l}$ infection. Aliment. Pharmacol. Ther., 2015, 41(6), 544-563.

[30] Messori, A., Fadda, V., Maratea, D., et al.: Effect of discounting on estimation of benefits determined by hepatitis $\mathrm{C}$ treatment. World J. Gastroenterol., 2012, 18(23), 3032-3034.

[31] Leidner, A. J., Chesson, H. W., Xu, F., et al.: Cost-effectiveness of hepatitis $\mathrm{C}$ treatment for patients in early stages of liver disease. Hepatology, 2015 March 16. doi: 10.1002/hep.27736. [Epub ahead of print]

[32] National Institute for Health and Care Excellence: Ledipasvir-sofosbuvir for treating chronic hepatitis C. Appraisal consultation document. www.nice.org.uk/guidance/gid-tag484/documents/ hepatitis-c-chronic-ledipasvirsofosbuvir-id742-appraisal-consultation-document 2

[33] Wong, W. W., Tu, H. A., Feld, J. J., et al.: Cost-effectiveness of screening for hepatitis C in Canada. CMAJ, 2015, 187(3), E110-E121.

(Makara Mihály dr., Budapest, Gyáli út 5-7., 1097 e-mail: michael@makara.md) 